\title{
ORGANIZATIONAL AND ECONOMIC MECHANISMS OF TRANSPORT SYSTEM DEVELOPMENT BASED ON LOGISTICS
}

\author{
INNA IRTYSHCHEVA, OLENA ISHCHENKO, JULIA BARABANOVA
}

\begin{abstract}
It is determined that the existence of a developed transport and logistics infrastructure is one of the defining dominants of the effective functioning of the transport and logistics system at the regional, national and international level, provides effective supply, marketing, production and social communications between the subjects of economic activity.

It is proved that the main directions of state policy implementation in the field of transport and logistics are: directions of innovative development of transport and logistics technologies on energy-saving and environmentally safe principles; construction of efficient economic systems in accordance with the principles of logistics and marketing; development of strategic planning; improvement of regulatory policy.

Institutional, organizational and economic mechanisms for ensuring the effective development of national transport and logistics systems have been researched and systematized, among which the following have been identified as priorities: the development of public-private partnerships and decentralization reform, which will solve the problems of financing infrastructure development, the formation of multi-branch integration structures (transport-logistics clusters, transport hubs and logistics-outsourcing platforms), which will improve the quality of transport and logistics services, intensification of the integration processes of the transport and logistics system in the international transport of the network, which will increase the competitiveness of the national economy, increase in productivity of transit potential and attraction of foreign investments in the development of the industry.
\end{abstract}

Keywords: transport and logistics systems, logistics, national economy, infrastructure, transport, strategic development.

\section{INTRODUCTION}

One of the defining conditions for the development of the national economy, ensuring the dynamism of socio-economic processes, an adequate level of business activity and a favorable business climate is the development of transport and logistics services. The problem of developing an efficient national logistics system capable of integrating and securing Ukraine's worthy place in the international market of transport and logistics services is of particular relevance in the context of the implementation of the European Development Vector. The experience of developed European countries shows that the development of transport and logistics services is the basis for competitive development of the national economy in the context of integration processes. 
The experience of European countries shows that the high level of development of the transport sector and logistics infrastructure in the country directly affects the economic efficiency of business and the increase of material resources turnover, leads to savings in transport, general logistics and warehousing costs. As a result of the development of national transport and logistics infrastructure, there is an increase in business activity and business mobility.

On this basis, the concept of improving the mechanisms of development of the national transport and logistics system needs to be further researched.

\section{RESUltS}

The analysis of the state of the transport and logistics system of Ukraine made it possible to identify the main problems, the solution of which lies in the field of improvement of economic, organizational, administrative, legal and institutional mechanisms of functioning of both national transport and logistics systems and the national economy as a whole. The main disadvantages that impede the effective development of the transport and logistics system include:

1) Poor quality of transport services, which in many cases is caused by the organization of work of transport carriers and the efforts to organize logistic processes on their own enterprises. In Ukraine, unlike most developed countries, integrated logistics services provided by specialized logistics companies are in their infancy. Most logistical services are combined with transport operations for a specific type of cargo, which involves different software and significant differentiation of documentary, financial and inform ation support, which among other things adversely affects the speed of freight and the cost of transportation, especially when combining different modes of transport.

2) High level of transportation deterioration. The analysis showed that the highest level of wear is observed primarily in rail and sea transport (more than 60\%), which leads to a decrease in quality and increase the risk of transport services.

3) Poor information support of the transportation process, which leads to certain complications of delivery control and coordination of logistics flows when conditions change.

4) Undeveloped rolling stock, which negatively affects the cost of transportation. This problem arises first of all for organizational reasons and is related to the unwillingness or inability to carry out picking of dispatch from different subscribers by domestic carriers and the lack of logistical coordination.

5) Low level of insurance culture among consignors, insufficiently developed system of cargo insurance.

6) It is difficult to organize the interaction of different modes of transport.

7) High energy consumption and low environmental friendliness of transport.

According to Y. Vovk, one of the systemic causes of the crisis in the transport industry is that market mechanisms have not become its main regulator at the moment. "The mechanisms of competition and self-organization of transport enterprises are underdeveloped, and the state regulation of the market of transport services is not effective enough. The monopoly in potentially competitive segments of rail transportation remains, and the existing inefficient management system of state transport enterprises leads to unsatisfactory results of their work, loss, inability to provide renewal of their own rolling stock and reconstruction of outdated transport infrastructure" [1, p. 10].

It is quite clear that the development of transport and logistics systems in Ukraine in a strategic context requires improvement of the existing management system based on the development of harmonized organizational and economic mechanisms and institutional legal mechanisms using leading foreign experience in this field.

Considering the transport and logistics system from the standpoint of the system management approach, we can conclude that it is an orderly managed system within which the range of transport and logistics services is created, creating the conditions for their most effective cross-sectoral and territorial distribution in accordance with the needs of consumers and providing uninterrupted supply. In accordance with these considerations, the transport and logistics system is an integrated socio- 
technical-information structure, themain purpose of which is the uninterrupted supply of the economy with transport and logistics services, characterized by the most optimal value for money. Fig. 1 shows the structure of the transport and logistics system in the context of the system-management approach.

Conditions of operation of transport and logistics system

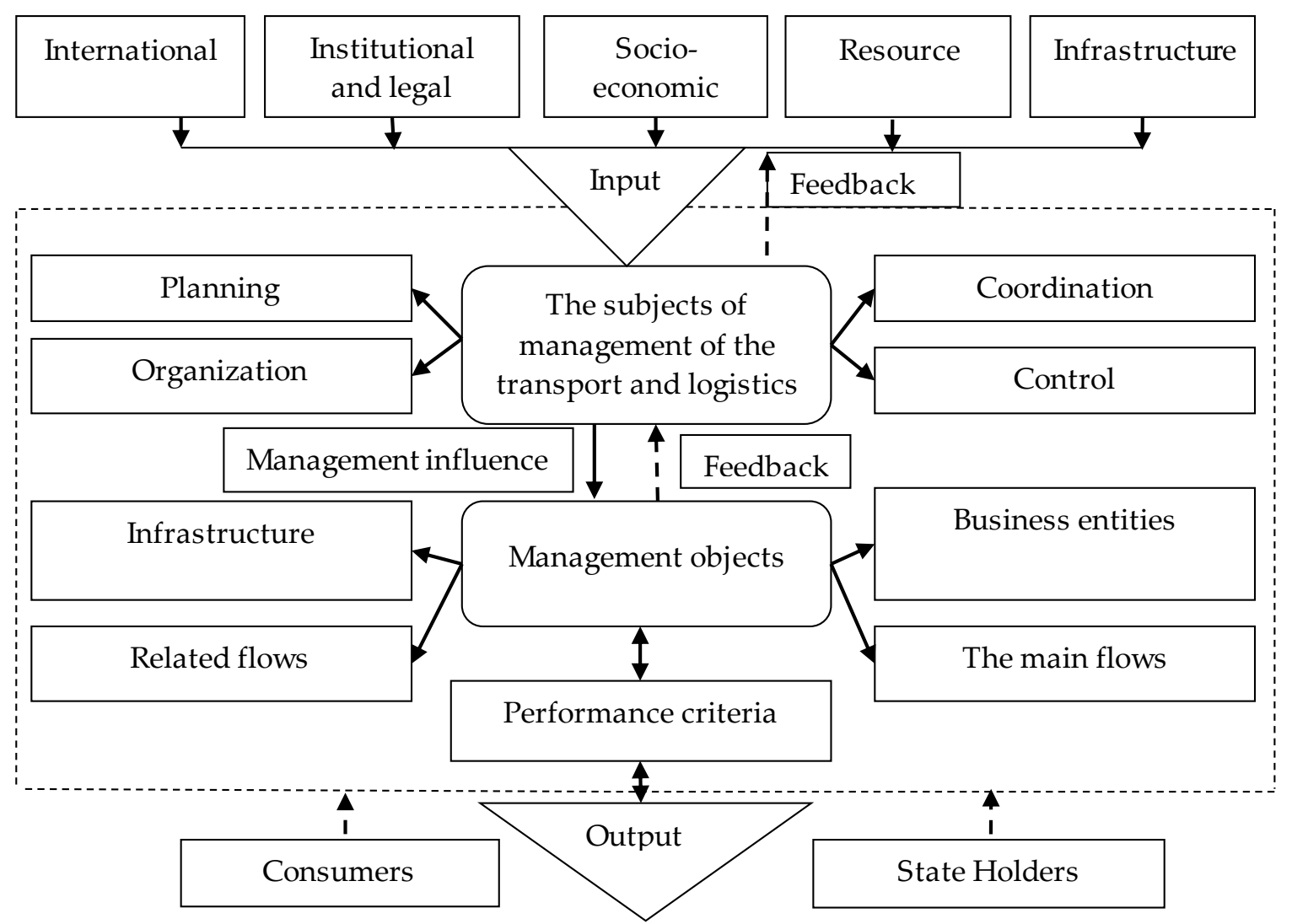

Fig. 1. Elements of transport and logistics system in the context of management approach.

* Source: Developed by the author

According to this approach, the operating factors determined by the set of factors are important factors and at the same time the input parameters of the national transport and logistics system functioning. International factors significantly influence the level and dynamics and trends of the development of transport and logistics flows through the formation of supply and demand for transport and logistics services and transit, the competitive price of transportation and accompanying services, the creation of joint projects and more. Given its favorable geographical location, Ukraine is one of the important transit territories and has considerable transport and logistics potential.

Therefore, the effective use of the existing transport and logistics potential of Ukraine depends on the development of external relations and implementation of effective reforms that will contribute to the full integration of the transport system in the international transport and logistics networks. One of the priority areas for the development of external relations in the field of transport is the inclusion of Ukraine in the European Logistics Networks operating within the framework of the Eastern Partnership in the context of the updated European TEN-T policy. In this context, we consider Vidyakina M.'s opinion "Given the priority of the East-West direction within the framework of the updated TEN-T policy, we can distinguish priority directions of Ukraine's cooperation within the framework of the Eastern Partnership transport panel. These include the development of the transport network in the format of integrated transport corridors; inclusion of inland waterways of Ukraine in the TEN-T regional network; analysis of the bottlenecks of the national transport network, which are combined with the Trans-European one; preparation of infrastructure projects to attract EU grant resources; developing mechanisms for the liberalization of road haulage with the EU and the Member States" $[2$, p. 33]. 
According to the Ministry of Infrastructure of Ukraine, the main priority areas of implementation of the Eastern Partnership programs within which joint projects in the field of transport are implemented are:

1) the development of the transport network in the form of integrated transport corridors, as well as the "reconnection" that has actually been lost due to the discontinuation of the Pan-European transport corridors;

2) analysis of the bottlenecks of the national transport network combined with the TEN-T network, preparation and prioritization of infrastructure projects for which EU grant resources will be allocated;

3) inclusion of Ukrainian Inland Waterways (Dnieper River, Southern Bug River and Ukrainian section of the Danube River) in the TEN-T regional network [3].

At the same time, full integration of Ukraine into international transport and logistics corridors and their transformation into effective transit potential requires considerable investments in material infrastructure, formation of efficient logistics centers, reform of customs and transit regimes. This requires a radical improvement of the existing institutional, legal and financial mechanisms for implementing the relevant programs.

Institutional legal prerequisites form a set of interconnected "rules of the game" governing the relations of entities in the field of transport and logistics services and, depending on the effectiveness of the created institutional legal mechanisms, create additional opportunities or barriers to the development of the relevant risk. In developed countries, institutional factors and related regulatory support are aimed at effectively regulating the transportation market and aiming at reducing transaction costs.

L. Chobal distinguishes the following components of the institutional environment of the transport complex:

- formal institutions (officially established by the authorities the rules and regulations that are binding on all participants of the transport complex);

- informal institutions (unwritten rules and traditions that are unofficial but have an impact on the functioning of many participants);

- mechanisms for identifying violations of rules and regulations by which offenders are identified;

- mechanisms for applying sanctions to violators "[4, p. 313].

As international experience shows, one of the priorities of institutional support for the development of transport and logistics systems is the introduction of public-private partnership mechanisms in this field. An effective public-private partnership system should provide a set of mutual benefits for both state and regional authorities and the private sector, in particular:

For the state these are additional possibilities:

- attracting private investment in the development of transport and logistics infrastructure and modernization of activities traditionally within the competence of public administration and financing (construction of transport and logistics complexes, terminals, ports, arrangement of water facilities, etc.);

- concentrating efforts on the most important economic and social security aspects of transport through outsourcing part of market services;

- attracting the best management, technology and technology from the private sector;

- cost and risk sharing;

- unloading of state bodies and differentiation of functions on management of infrastructure and transport services;

- reduction of the state monopoly influence on the development of transport, reduction of the administrative apparatus and promotion of the development of competitive relations;

- improving efficiency, reducing project implementation times and improving the quality of service to end consumers.

In turn, private equity can receive the following benefits:

- expanding market share by entering the public services market, where traditionally there is steady demand; 
- priority state assistance in the implementation of joint investment projects, reduction of administrative barriers;

- sharing risks and costs with the state;

- providing state guarantees of minimum profitability of the project, partial refund of funds in case of unsuccessful implementation of the project due to the fault of the state partner.

In Ukraine, the mechanism of public-private partnership implementation is governed by the law of Ukraine "On Public-Private Partnership", which defines the basic conditions for the implementation of joint projects in this field. The law defines the basic principles on which relations between the state and business should be built:

- equality before the law of public and private partners;

- prohibition of any discrimination against the rights of public or private partners;

- aligning the interests of public and private partners for mutual benefit;

- ensuring higher efficiency of activity than in the case of such activity by a public partner without involvement of a private partner;

- invariance throughout the term of the contract concluded within the framework of public-private partnership, purpose and form of ownership of objects that are state or communal property or belong to the Autonom ous Republic of Crimea, transferred to a private partner;

- recognition by public and private partners of the rights and obligations stipulated by the legislation of Ukraine and defined by the terms of the contract concluded within the framework of the public-private partnership;

- fair sharing between the public and private partners of the risks associated with the implementation of public-private partnership contracts;

- definition of a private partner on a competitive basis, except in cases established by the law [5].

At the same time, according to the experts of the Institute for Strategic Studies under the President of Ukraine, the current legislation on public-private partnership in Ukraine has several disadvantages:

- First, there is no minimum share of participation in the private partner project (in particular, in developed countries, the minimum share of private funding is $25 \%$ ). In this regard, even a minimal proportion of private funding in a joint project allows it to be classified as a public-private partnership, transferring most of the responsibility to the state.

- Second, there are no well-defined mechanisms for practical implementation (defining the stages of implementation of public-private partnership projects, creating motivation for foreign investors, etc.).

- Third, according to Art. 7 public-private partnership extends to entities that are state-owned or communal-owned or owned by the Autonomous Republic of Crimea; this makes it impossible to implement projects such as the construction of facilities by a private partner and then transfer them to a state (municipal) partner.

- Fourth, the role of the State Regional Development Fund in financing public-private partnership projects "and the peculiarities of using public-private partnership as a mechanism for implementing a new regional policy" [6].

Therefore, despite some changes in this area, the use of public-private partnership mechanisms in the transport sector has not become widespread due to the poorly developed regulatory and legal mechanisms of public-private partnerships in the transport and logistics sector, lack of rights and guarantees for investors, corruption and lack of trust between the state and the private sector.

Resource support for the development of transport and logistics systems directly affects the quality and tariff policy in the field of transport services. An important factor in the provision of resources is the development of the personnel capacity of the transport and logistics system. The availability of qualified personnel is one of the main prerequisites for improving the level of services provided by logistics providers, the productivity of trade and logistics companies.

Despite the high level of teaching and professional skills in some sub-sectors of the transport system (aviation and rail technology, mechanical engineering, road construction), there is a shortage of specialists in the field of supply chain management, inter-branch logistics, traffic information management. One of the obstacles for Ukrainian logistics providers, transport officials and 
management staff is their lack of proficiency in English. In view of this, important directions for improving the personnel support for the development of national transport and logistics systems are the development of targeted sectoral training programs and training for employees of the transport and logistics sector, which should be aimed at:

- professional training of personnel;

- improvement of educational programs for higher education institutions in the field of logistics in accordance with current world trends and needs;

- development of voluntary schemes with (international) qualification standards;

- ensuring the participation of national scientists in international projects in the field of STI;

- introduction of English and other foreign language courses, which should become a prerequisite for career advancement.

One of the most problematic and at the same time decisive tasks of providing resources for the development of national transport and logistics systems and infrastructure is financial support. An analysis of the state funding of projects and programs in the industry has shown that, with limited state and regional funds, there is a significant under-financing of the construction and rehabilitation of strategically important infrastructure, such as roads, ports, railway stations and rolling stock.

In the face of scarcity of public financial resources, a large part of the projects in the industry are financed with the involvement of international financial assistance, which eventually leads to the accumulation of debt.

According to O. Ovsyannikova, the main directions of improving the financing system of the transport sector of Ukraine are:

- "to develop a long-term financing plan for the transport sector with a view to developing infrastructure, in particular with careful planning in line with strategic priorities, timing and asset lifecycle, as well as on the return on investment to ensure efficient spending;

- to ensure that the State Road Fund fulfills its goals in 2019;

- create favorable conditions for attracting private equity investments in the development of the transport sector with obviously viable public-private transport partnership projects;

- ensure a transparent system of public procurement, communication and disclosure of budget planning and spending to demonstrate financial discipline to the public;

- encourage MFO investment in the development of the transport sector;

- develop and apply innovative financial instruments and mechanisms in the long run to unlock private capital flows into the transport sector (green investments, mezzanine financing, project financing, including bonds and risk-sharing instruments) with state or MFO support "[7, p. 35-36].

In our opinion, in reforming the financial support system for the development of national transport logistics systems, it would be useful to take advantage of Poland's experience in this field, especially given the European vector of Ukraine's development. This is due to the fact that Poland can be compared to Ukraine in terms of a large number of indicators and structural parameters of the economy. At the same time, despite the lack of access to international maritime routes and more limited transport and logistics, transit and infrastructure potential in comparison with Ukraine, Poland has today reached the leadership among the post-socialist countries in most parameters of the transport and logistics system development and achieved a high level of logistic efficiency.

In particular, on the basis of the conducted research, Borschevsky V. notes the following reforms applied by Poland, which contributed to the achievement of stable financial condition of the transport and logistics industry and ensured the efficient functioning of transport systems:

1) liberalization of economy and foreign economic activity, which stimulated the development of entrepreneurship and significantly improved business conditions. The broad involvement of private investment on the basis of public-private partnerships, the reduction of state monopolies and the corporatization of the transport and logistics business had a positive impact on the financing of infrastructure and the transport sector. These measures stimulated the inflow of investments into the industry and gave impetus to the development of competition in the market of transport services; 
2) change of administrative-territorial structure and deep decentralization of power, which allowed to form an effective system of local self-government on the basis of delegation of a considerable part of financial and administrative-administrative powers, including in the sphere of development of regional transport and logistics systems. This was the impetus for deep modernization and improvement of the road economy, reconstruction of roads of local importance and creation of objects of transport and logistical infrastructure at the expense of local budgets and territorial communities. The synergies in the field have also been facilitated by the joint efforts of local communities and businesses through joint implementation of investment projects of regional and interregional transport infrastructure development.

3) adapting to the requirements and standards of the EU in building civil society institutions. First of all, it concerned the formation of a network of NGOs and other non-governmental institutions whose activities ensured the effective use of EU financial support instruments for the candidate countries. These programs, as noted earlier, have attracted significant sums of money from Poland for the development of various links in the transport infrastructure [8].

Despite some efforts and developments in the areas under consideration in Ukraine, some issues regarding the implementation of decentralization reforms, the development of public-private partnerships and the formation of effective mechanisms for involving the private sector in the development and modernization of regional transport and logistics infrastructure remain unresolved. Solving these goals will reduce the financial burden on the state budget and promote the targeted use of financial resources, increase transparency of procedures and help reduce regional disparities in the development of transport infrastructure.

According to a considerable part of national scientists, the solution of problems concerning the improvement of the organizational support system and improvement of the quality of transport and logistics services is the formation of cross-sectoral territorial, interregional and intermodal organizational structures, in particular transport and logistics clusters, nodes, specialized platforms, etc. In particular, scientists Irtyshcheva I., Minakova O., and Khristenko O. emphasize that "the organizational structure of the transport and logistics system of Ukraine should consist of five levels of logistical interaction:

- interaction of objects of transport and logistics infrastructure (terminal and cargo complexes, warehouses, enterprises of various types of transport and transport and logistics service, etc.);

- logistic transport centers of local, regional and international destination;

- regional logistics transport systems;

- logistics transport clusters;

- integrated transport and logistics system of Ukraine (subsystem of the economic system of the country and international transport and logistics systems) [9, p. 148]. Such a structure will ensure the creation of a wide range of high-quality, secure and low-cost transport and logistics services that meet the expectations and requirements of stakeholders (consumers, carriers, state-holders).

The cluster approach to the formation of transport and logistics systems has been widely used in the economies of developed countries, in particular the USA, Japan, China, India, and is a priority organizational direction for the development of transport systems within the EU. The organizational structure of transport and logistics systems involves the formation of support logistics centers and cooperating regional transport and logistics clusters, which allows to optimize the systems of cargo flows between countries. "The European network of transport and logistics clusters comprises 25 prim ary and about 60 secondary transport and logistics clusters, which fall into one of three categories:

1) port transport and logistics clusters (Valencia Cluster, Spain);

2) border transport and logistics clusters;

3) regional transport and logistics clusters "[10, p. 70].

According to O. Polyakova and O. Shramenko, "the impact of transport and logistics infrastructure on long-term economic growth is carried out in five main directions:

1) as a direct factor of production;

2) as an element of other factors of production; 
3) as an incentive to increase aggregate demand;

4) as an incentive to accumulate factors of production;

5) as an instrument of industrial policy" [11, p. 132].

Therefore, the use of a cluster approach to the organization of transport and logistics services in Ukraine can be an important factor in improving the quality of basic (passenger and freight transportation) and accompanying (information support, service, cargo insurance, customs procedures, etc.) services and improving the business climate in the regions. Promising directions of cluster formation are their placement in Ukraine near large industrial and agricultural centers along the directions of international transport corridors.

According to O. Karpenko and E. Osipova, the creation of logistics and outsourcing platforms is an important area of organizational support for the development of transport and logistics systems and their coordination at the macro level. Under the logistics-outsourcing platform, the authors propose to understand "a coordinating and integrated mechanism for managing and transforming material, information and other flows, which integrates elements of the transport and logistics system at the macro level and ensures high efficiency of the goals of these elements. The logistics and outsourcing platform should be considered as an infrastructure unit of the region's economic system. The main tasks of the logistics and outsourcing platform are to provide transport and logistics services at minimal costs for logistics services and logistics infrastructure through the cooperation of transport and logistics companies providing specialized logistics services "[12].

\section{CONCLUSIONS}

Building an effective national transport and logistics potential and its rational use in today's changing environment requires a comprehensive systematic approach and the creation of an effective strategic management system that takes into account its existing and potential technical, organizational, resource and functional properties.

The formation of logistics and outsourcing platforms will help to integrate and balance processes, management, service, optimization of freight flows of various types, which will lead to a shortening of the delivery time of goods and improve the quality of customer service. Logistics-outsourcing platforms will also create the conditions for the introduction of new IT technologies and the expansion of information support, control and administration of freight traffic, which at the same time will help to accelerate the payback period of projects. Also, the implementation of transport-logistic platforms and clusters will have a positive impact on the socio-economic development of the regions where they are located through: increasing jobs and improving infrastructure, creating a favorable business environment, developing small and medium-sized businesses.

\section{REFERENCES}

[1] Vovk Y. Analysis of the state of the transport system of Ukraine and prospects for its development. Socio-Economic Problems and the State, 2 (13) (2015), 5-15. Available at: http://sepd.tntu.edu.ua/images/stories/pdf/2015/15vyypyr.pdf (in Ukrainian)

[2] Vidyakina M. Institutional aspects of the transformation of the EU's common transport policy. Proceedings of Scientific Works of Cherkasy State Technological University Series Economic Sciences, 44 (1) (2017), 26 - 34. Available at: http://ven.chdtu.edu.ua/article/view/110675/105599 (in Ukrainian)

[3] Ministry of Infrastructure of Ukraine, (2019). Available at: https://mtu.gov.ua/content/shidnepartnerstvo.html (in Ukrainian)

[4] Chobal L.Yu. Instituts basis of development of the transport complex in Ukraine. Scientific Bulletin of UNFU, 23 (8) (2013), 312-316. Available at: https://nv.nltu.edu.ua/Archive/2013/23_8/312_Czob.pdf (in Ukrainian)

[5] Law of Ukraine "On Public-Private Partnership", (2019). Available at: http://zakon0.rada.gov.ua/laws/show/2404-17 (in Ukrainian) 
[6] Analytical note. National Institute for Strategic Studies, (2019). Avilable at: http://www.niss.gov.ua/articles/1239/ (in Ukrainian)

[7] Ovsyannikov Y. Financing of the Ukrainian transport sector: current state and prospects for development. Finansovye uslugi, 2 (2017), 34-37. (in Ukrainian)

[8] Borschevsky V. Modernization of transport infrastructure in the process of EU accession: Poland's experience for Ukraine. International Relations, Part "Economic Sciences", 9 (2016). Available at: http://journals.iir.kiev.ua/index.php/ec_n/article/view/3062/2750 (in Ukrainian)

[9] Irtyshcheva I., Minakova S., Khristenko O. Structure of the transport and logistics system of Ukraine. Global and National Problems of Economics, 4 (2015), 146-149. (in Ukrainian)

[10] Smyrnov I. Processes of transport-logistic clustering in the European Union and Ukraine: regional dimension. Pskov Journal for Regional Studies, 15 (2013), 66-75. (in Russian)

[11] Polyakova O., Shramenko O. Current trends in the development of transport and logistics infrastructure in Ukraine and in the world. The bulletin of transport and industry economics, 58 (2017), 126-134. Available at: http://nbuv.gov.ua/UJRN/Vetp_2017_58_17 (in Ukrainian)

[12] Karpenko O., Osypova E. Logistics and outsourcing platform as a basis for the formation of transport and logistics system in the region. Efektyvna ekonomika, 12 (2017). http://www.economy.nayka.com.ua/?op=1\&z=6000 (in Ukrainian)

Address: Inna Irtyshcheva, Olena Ishchenko, Julia Barabanova, Admiral Makarov National University of Shipbuilding, 9, Heroyiv Ukraine Ave., Mykolayiv, 54025, Ukraine.

E-mail: innauamd@gmail.com, olena.ishchenko@nuos.edu.ua, juliatrushliakova@gmail.com

Received: 11.11.2019; revised: 06.12.2019.

Іртищева Інна, Іщенко Олена, Барабанова Юлія. Організаційно-економічні механізми розвитку транспортної системи на основі логістики. Журнал Прикарпатського університету імені Василя Стефаника, 6 (3-4) (2019), 37-45.

Визначено, що наявність розвинутої транспортно-логістичної інфраструктури є однією 3 визначальних домінант ефективного функціонування транспортно-логістичної системи регіонального, національного та міжнародного рівня, забезпечує ефективні постачальницько-збутові, наукововиробничі та соціальні комунікації між суб'єктами економічної діяльності.

Доведено, що основними напрямками реалізації державної політики у транспортнологістичній галузі є: інноваційний розвиток транспортних і догістичних технологій на енергоощадних та екологічно безпечних засадах; побудова ефективних економічних систем із врахуванням принципів логістики і маркетингу; розвиток стратегічного планування; удосконалення регуляторної політики.

Досліджено та систематизовано інституційні, організаційні та економічні механізми забезпечення ефективного розвитку національної транспортно-логістичної системи, серед яких у якості пріоритетних визначено: розвиток державно-приватного партнерства та реформи децентралізації, що дозволить вирішити проблеми з фінансування розвитку інфраструктури, формування інтеграційних багатогалузевих структур (транспортно-логістичних кластерів, транспортних вуздів та логістично-аутсорсингових платформ), що сприятиме підвищенню якості транспортно-логістичних послуг, активізація інтеграційних процесів транспортно-логістичної системи в міжнародні транспорті мережі, що забезпечить підвищення конкурентоспроможності національної економіки, зростання продуктивності транзитного потенціалу та залучення іноземних інвестицій у розвиток галузі.

Кдючові слова: транспортно-логістичні системи, логістика, національна економіка, інфраструктура, транспорт, стратегічний розвиток. 